minister of Akbar, the honour of having invented the modern land-revenue system of India. $\mathrm{He}$, of course, merely modified and improved a system which had been in existence for centuries before his time. But he probably found the old Prakrit term rajjuka in common use, and naturally enquired into its meaning, which he forthwith translated into Persian sar-i rishta dār. It is true that a modern sarishtadar's duties are no longer confined to settlement work, nor does he often condescend to hold the rope himself. But the rope is still used for measuring lands in settlement proceedings, where it has not been superseded by the bamboo laggi, or the more scientific Gunter's chain, and Dr. Bühler's explanation is undoubtedly the solution of the puzzle which has exercised so many English officers in India, why the highly respectable and experienced head of a large office should be designated by the simple title of "one who holds the end of a rope." - Yours truly,

\title{
JoHN BeAMES.
}

\section{Vidyädhara Pițaka.}

In the letter from Mons. Louis de la Vallée Poussin, in our last issue, readers are requested to correct the following misprints :-

p. 435, lines 13, 23, for Tapās read Japās.

p. 436, line 6, " correct " collect.

" line $29 \quad$ " Kangika " Kausika.

\section{Archatological Research.}

Sir,-CThe discussion of Hofrath G. Bühler's proposals as to future Archæological Research in India ended without any definite vote of our meeting on June 11th; and I myself, speaking late and pressed for time, could say little. I have, therefore, the honour to offer the following remarks in black and white:- 
The first point in the matter is, that in the present state of Indian finance the Government of India cannot be expected to spend much money on research.

The second is, that any researches carried out by other machinery are likely to be unsystematic in execution, and still more in record, especially in the case of excavations. These, if not most carefully planned and supervised, are apt to obliterate more than they bring to light. And unless their record is kept, at the pit's mouth, by a skilled observer, what is brought to light might often much better have been left under the kindly protection of the earth, until time and funds were available for deliberate and thorough research. It happens that small objects are overlooked or stolen by the coolies; that the exact position of objects found escapes observation, or is even misstated; and that heavy materials, such as sculptures or walls, are left exposed, and destroyed, misappropriated, or injured by mere weatherwear. All these things have happened within my own experience, and in that of many other members of our Society. I need only touch upon the obvious probability of waste of money.

What has chiefly to be considered is how the risk of fruitless or mischievous research is to be, as far as possible, avoided, at reduced expense, until better days come.

In quoting Hofrath Bühler's paper I must, of course, trust to memory; and write subject to correction. But his principal point, as I take it, is that there should be in each province an officer acting as the archæological adviser of Government; without consulting whom (a) No expenditure of public funds on archæological research should be sanctioned.

(b) No object of archæological interest in the possession (or under the control) of Government should be disposed of.

(c) No excavation, or other research, likely to alter the condition or position of any such object should be encouraged by any public servant, even in regard to places and objects not directly under such control. 
(d) And through whom all such researches should, as far as possible, be reported to the Provincial Government.

This proposal, in a general way, appeared to have had the approval of the meeting. It is eminently practicable, as might be expected from a scholar distinguished, amongst those who knew him well, for administrative skill and intimate knowledge of district and political business in the mofussil.

In a province where financial exigencies prevent the appointment of a special Archæological Surveyor, it may frequently be found possible to assign the duties of the office to some qualified officer of the Revenue, Educational, or Public Works Department, " in addition to his own duties," with or without addition to his personal salary; but, of course, with a proper establishment and accommodation, which need not be very costly.

Only those who have very lately served in India can know how much the work of the past has increased general interest and individual acquirements, in archæology as in other sciences, amongst Her Majesty's servants in that country. In the departments named the average level of acquirement in such matters is such as would have earned special notice only twenty years ago. I am speaking here especially of Archæology, which comes most home to their officers. Other branches of science are more in the way of those of other departments, though there is no branch of the service without antiquaries, particularly numismatists. There are, indeed, competent scholars outside of the services; but their presence only requires acknowledgment here, as an archæological officer of Government must necessarily be its servant, and under its full control. The business is one which could not, I think, be properly assigned even to the local learned societies.

I need not here discuss the duties of an archæological surveyor, well enough ascertained by experience, nor the methods of research which he should adopt, nor even the fields of operation. Enough about these matters was said at the meeting of the 11th of June by other speakers. 
But there is one point of detail too often neglected in India, and that is the necessity of recording possession and proper custody of such objects as sculptures. These are not unfrequently brought into offices, courts, gardens of public buildings, or store-yards, fit enough to hold them, at least for a time. But it commonly happens that they are simply left there, and not entered in the stock-books as Government property; for the custody of which some particular public servant is responsible. In consequence, their provenance and ownership soon become mere matter of tradition amongst underlings; and they are too often mislaid or misappropriated.

It should be a standing order of all departments that such objects should be entered in the stock-books, just as much as office chairs and tables worth a few rupees, and copy of the entry sent to the Archæological Surveyor.

June 12th, 1895.

W. F. Sinclair.

To the Secretary of the Royal Asiatic Society.

4. The J Aiss.

The Homestead, Barnes.

7 th July, 1895.

Dear SIR,-With reference to the paper recently read before the Society on the subject of the Jain religion, it may be of interest to members to have the following translation of the opening words of the 10tth Sutta of the Majjhima Nikāya:-

"Thus have I heard. Once on a time the Blessed One was dwelling among the Sakyas in Sãmagāma. Now it was at this time that Nigaṇţa Nātaputta had just died at Pāvā. By reason of his death the Nigantthas were broken up, divided into two camps, filled with dissension and contention, and were always wounding one another with 